\title{
CELL CYCLE KINETICS AND CYTOGENETIC CHANGES IN HUMAN LYMPHOCYTES EXPOSED TO OESTRADIOL IN VITRO
}

\author{
DJELIĆ N*, SPREMO-POTPAREVIĆ BILJANA**, MARKOVIĆ BILJANA*, ŽIVKOVIĆ LADA** \\ and DJELIĆ DIJANA* \\ *Faculty of Veterinary Medicine, Belgrade \\ ${ }^{* \star}$ Faculty of Pharmacy, Belgrade \\ (Received 9. January 2006)
}

Metabolic conversion of oestrogen phenolic groups may create conditions of oxidative stress accompanied by damage of cellular macromolecules including DNA. The aim of this investigation was to evaluate the cell cycle kinetics and possible cytogenetic changes in cultured human peripheral blood lymphocytes exposed to seven experimental concentrations of $17 \beta$-oestradiol (range $10^{-10} \mathrm{M}$ to $10^{-4}$ M).

Cell cycle kinetics was analysed on metaphase spreads prepared for a standard analysis of sister-chromatid exchanges (SCEs) stained by fluorescent-plus-Giemsa (FPG) technique. Cytogenetic changes were monitored by analysis of chromosome damage (gaps and breaks), structural and numerical aberrations.

On the basis of the obtained results it can be concluded that oestradiol has no significant influence on cell cycle kinetics and mitotic index of cultured human lymphocytes. However, at estradiol concentration of $7 \times 10^{-6} \mathrm{M}$, and at higher concentrations used in this experiment, there was a significant increase of gaps, breaks and aneuploidies. On the other hand, oestradiol treatment has not changed the frequency of polyploid cells. Therefore, it can be concluded that high concentrations of oestradiol pose some genetic risk detectable at cytogenetic level.

Key words: cell cycle kinetics, chromosome aberration, mutagen, oestradiol.

\section{INTRODUCTION}

It has been demonstrated in the late 1930 s and early 1940 s that oestradiol and its esters induce tumors in guinea pigs and mice (IARC, 1987). Since that time, numerous data concerning tumor induction by oestrogens have been accumulated, and various rodent tumor models have been introduced (IARC, 1999). Besides, epidemiological studies pointed to an increased risk of breast and uterine tumors in women treated with oestrogens (Liehr, 2001). 
Oestrogens can promote tumor growth due to receptor-mediated stimulation of mitotic divisions (Platet et al., 2004). However, since oestrogens exhibited genotoxic effects in various systems in vitro and in vivo (Liehr and Roy, 1990; Rajapakse et al., 2005), it is clear that they actually act as carcinogens capable not only to stimulate mitosis (tumor promotors), but also to elevate the mutation rate in susceptible cells (tumor initiators). These findings shed a new light on the analysis of the relevance of hormones in malignant transformations.

Biochemical and molecular biological analysis provided an insight into the mechanisms of malignant transformations caused by oestrogens. Induction of kidney tumors in hamsters chronically exposed to oestrogens represents one of the most useful models for examination of carcinogenic effects of oestrogens and related compounds (Papa et al., 2003). It has been shown that a low picogram range of oestrogen concentrations causes normal physiological responses in the target tissues. However, at elevated doses oestrogens induce tumors in laboratory animals (kidney tumor in Syrian hamsters, uterine tumors in mice etc.) (Krikman, 1959; Walker, 1983). Likewise, it has been clearly demonstrated that synthetic nonsteroidal oestrogen diethylstilbestrol (DES) exhibits carcinogenic properties (IARC, 1979).

At elevated concentrations of oestrogens, metabolic reactions which lead to the formation of free radicals may become the predominant biochemical activity, thus overshadowing their hormonal effects. Since oestrogens are phenols, the metabolism of their phenolic moiety, while harmless at low oestrogen tissue levels, may exert deleterious effects at high concentrations (Liehr and Roy, 1990; Cavalieri and Rogan, 2004). The first step in redox cycling of oestrogens is their enzymatic conversion to catecholoestrogens (Liehr and Roy, 1990). Catecholoestrogens and diethylstilbestrol posses a catechol group so they can be involved in a redox cycling which create conditions of oxidative stress accompanied by covalent damage of macromolecules including DNA (Cavalieri et al., 2000). In the kidney, which is a target organ of oestrogen-induced carcinogenesis, estrogens induce both DNA adducts (Liehr et al., 1991) and chromosome alterations (gaps, breaks and endoreduplicated cells) (Banerjee et al., 1994).

In our previous studies we demonstrated that $17 \beta$-oestradiol induces sisterchromatid exchanges (Djelić and Djelić, 2002) and micronuclei (Djelić et al., 2005) in cultured human lymphocytes. These results are in accordance with findings of genotoxic effects of natural (Ahmad et al., 2000) and synthetic oestrogens (Hundal et al., 1997) in human lymphocytes in vitro.

Bearing in mind all the above mentioned, the objectives of the present study were to examine the mitotic activity, cell cycle kinetics and the appearance of chromosome aberrations in cultured human lymphocytes exposed to $17 \beta$ oestradiol. Experimental concentrations of oestradiol were calculated to correspond to a wide range of concentrations in human blood; i.e physiological level, therapeutic range and up to 30 fold maximal therapeutic concentration for humans. This investigation should contribute to a better understanding of genetic risk under a wide range of oestradiol concentrations. 


\section{MATERIALS AND METHODS}

Blood samples, culture conditions and treatment. Human peripheral blood lymphocyte cultures were set up according to a slight modification of the protocol described by Evans and O'Riordan (1975). Heparinised whole blood samples $(0.8 \mathrm{~mL})$ obtained by venipuncture form three healthy men under 35 years of age, were added to vials with $9.2 \mathrm{~mL}$ of Parker 199 medium (Torlak, Belgrade) containing $30 \%$ of inactivated calf serum (Serva, Heidelberg, Germany) and $5 \mu \mathrm{g} / \mathrm{mL}$ of phytohaemagglutinin (PHA) (Murex Diagnostics Ltd., Dartford, England). Cultures were incubated in the dark for $72 \mathrm{~h}$ at $37 \pm 0.2^{\circ} \mathrm{C}$.

Exactly $47 \mathrm{~h}$ and $30 \mathrm{~min}$ after the beginning of incubation $17 \beta$-oestradiol (Sigma Chemical Co., St. Louis, MO, CAS No. 50-28-2) was added to the cultivation vials in such amounts as to obtain final experimental concentrations of: $10^{-10} \mathrm{M}, 10^{-9} \mathrm{M}, 7 \times 10^{-8} \mathrm{M}, 3.5 \times 10^{-6} \mathrm{M}, 7 \times 10^{-6} \mathrm{M}, 7 \times 10^{-5} \mathrm{M}$ and $2.1 \times 10^{-4} \mathrm{M}$. The calculations of concentrations of oestradiol comparable to the blood level of oestradiol-treated women are described elsewhere (Djelić and Djelić, 2002). The concentration of $10^{-10} \mathrm{M}$ is comparable to the physiological blood level in women. Three concentrations $7 \times 10^{-8} \mathrm{M}, 3.5 \times 10^{-6} \mathrm{M}, 7 \times 10^{-6} \mathrm{M}$ correspond to minimal, average and maximal therapeutic doses in human medicine, respectively. Finally, the concentration of $7 \times 10^{-5} \mathrm{M}$ corresponds to 10 -fold maximal dose, and $2.1 \times 10^{-4}$ $\mathrm{M}$ to 30 -fold maximal dose in women. The negative control was dimethylsulfoxide (DMSO), the solvent of oestradiol. The acetone solution of N-methyl-N'-nitro-Nnitrosoguanidine (MNNG, Chemical Co., St. Louis, MO, CAS No 70-25-7) was used as the positive control at a final concentration of $10^{-6} \mathrm{M}$.

In vitro cytogenetic test. Two hours before harvesting colcemid $(0.5 \mu \mathrm{g} / \mathrm{ml})$ (Ciba, Basel, Switzerland) was added to the cultures. Hypotonic condition was achieved by $0.075 \mathrm{M} \mathrm{KCl}$. After three standard cycles of fixation in methanol-acetic acid $(3: 1, v / v)$, cell suspension was dropped on chilled grease-free microscopic slides, air dried and stained in 10\% Giemsa (Kemika, Zagreb, Croatia). For each experimental concentration, as well as the for the controls, 150 mitotic plates were examined on coded slides. Scoring of gaps and breaks was performed according to the established criteria (Brogger, 1982). Mitotic index (MI) was calculated as percentage of cells in mitosis on a count of at least 2000 cells.

Cell cycle kinetics. In order to distinguish between cells in the first, second and third mitotic division, 5-bromo-2'-deoxyuridine (BrdUrd, Chemical Co., St. Louis, MO) was added to cultures one hour after the addition of PHA in order to prevent possible competition for the same binding sites at cell membranes. Treatment and harvest of mitosis were performed the same way as described in the cytogenetic test. After at least 2 days of ageing, metaphase spreads were stained by Fluorescence-plus-Giemsa (FPG) method (Perry and Wolff, 1974). The calculation of cell proliferation index was achieved using the formula $\mathrm{CPI}=\left(\mathrm{M}_{1}+\right.$ $\left.2 M_{2}+3 M_{3}\right) / 100$, where $M_{1}, M_{2}$ and $M_{3}$ represent the percentage of cells in the first, second and third mitosis, respectively. For each donor, at least 200 metaphases were scored for CPI calcualtion. 
Statistical analysis. Statistical analysis of cytogenetic data was performed by Student's $t$-test. Cell cycle kinetics data were analysed by $\chi^{2}$ test. The differences with $P \leq 0.05$ value were considered as significant.

\section{RESULTS}

The obtained results of mitotic indices are presented in Table 1. The percentage of cells in mitosis was lowered by $33.7 \%$ in cultures treated with the positive control (MNNG) compared to the negative control (the solvent, DMSO). Evidently, only the positive control caused a significant $(P<0.01)$ decrease of $\mathrm{Ml}$ compared to the negative control. Treatment with oestradiol has caused insignificant changes from the control values $(P>0.05)$. The percentage of cells in mitosis in oestradiol-treated cultures ranged from $4.08 \%$ to $6.48 \%$.

Table 1. Mitotic index of cultured human lymphocytes treated with $17 \beta$-oestradiol

\begin{tabular}{|c|c|c|c|}
\hline Concentration & $\begin{array}{c}\text { Number of } \\
\text { cells observed }\end{array}$ & $\begin{array}{c}\text { Mitotic index } \\
(\%)\end{array}$ & $\begin{array}{l}\text { Percentage of } \\
\text { control value }\end{array}$ \\
\hline Negative control (DMSO) & 2047 & 5.34 & 100.00 \\
\hline Oestradiol $10^{-10} \mathrm{M}$ & 2266 & 4.91 & 91.95 \\
\hline Oestradiol 10-9 M & 2278 & 5.42 & 101.50 \\
\hline Oestradiol $7 \times 10^{-8} \mathrm{M}$ & 2042 & 5.17 & 96.82 \\
\hline Oestradiol $3.5 \times 10^{-6} \mathrm{M}$ & 2019 & 6.29 & 117.79 \\
\hline Oestradiol $7 \times 10^{-6} \mathrm{M}$ & 2108 & 6.48 & 121.35 \\
\hline Oestradiol $7 \times 10^{-5} \mathrm{M}$ & 2317 & 4.37 & 81.84 \\
\hline Oestradiol $2.1 \times 10^{-4} \mathrm{M}$ & 2293 & 4.08 & 76.40 \\
\hline Positive control (MNNG) & 2006 & $3.54^{\star \star}$ & 66.29 \\
\hline
\end{tabular}

** $P<0.01$; (Student's $t$-test).

The cell cycle kinetics was evaluated by cell proliferation index (CPI), a parameter that represents the ratio of cells in the first, second and third mitosis (Table 2). Since the chromosomes were stained according to FPG procedure it was possible to clearly distinguish cells in the first, second and third mitotic cycle. The difference between chromosomes in the first and second mitosis is showed on Fig. 1. Obviously, in the first mitosis both chromatids are darkly stained, whereas in the second one chromatid is darkly and another sister chromatid is lightly stained. The analysis of CPI revealed no significant differences in the cell cycle kinetics after the treatment with oestradiol. In cultures treated with positive control the CPI value is lowered by $15.9 \%$ compared to the negative control $(P<0.01)$. 
Acta Veterinaria (Beograd), Vol. 56. No. 1, 37-48, 2006.

Djelić $\mathrm{N}$ et al.: Cell cycle kinetics and cytogenetic changes

in human lymphocytes exposed to oestradiol in vitro

Table 2. Proliferative kinetics of human lymphocytes treated with $17 \beta$ - oestradiol

\begin{tabular}{|c|c|c|c|c|c|c|c|c|}
\hline \multirow{2}{*}{ Concentration } & \multirow{2}{*}{$\begin{array}{c}\text { Number } \\
\text { of cell } \\
\text { observed }\end{array}$} & \multicolumn{2}{|c|}{ M1 } & \multicolumn{2}{|c|}{$\mathrm{M} 2$} & \multicolumn{2}{|c|}{ M3 } & \multirow{2}{*}{$\mathrm{CPI}$} \\
\hline & & No & $\%$ & No & $\%$ & No & $\%$ & \\
\hline $\begin{array}{l}\text { Negative control } \\
\text { (DMSO) }\end{array}$ & 612 & 191 & 31.2 & 342 & 55.9 & 79 & 12.9 & 1.82 \\
\hline Oestradiol $10^{-10} \mathrm{M}$ & 623 & 190 & 30.5 & 369 & 59.2 & 64 & 10.3 & 1.80 \\
\hline Oestradiol $10^{-9} \mathrm{M}$ & 640 & 203 & 31.7 & 381 & 59.5 & 56 & 8.8 & 1.77 \\
\hline Oestradiol 7x10-8 M & 633 & 213 & 33.6 & 362 & 57.2 & 58 & 9.2 & 1.76 \\
\hline Oestradiol $3.5 \times 10^{-6} \mathrm{M}$ & 600 & 186 & 31.0 & 349 & 58.2 & 65 & 10.8 & 1.80 \\
\hline Oestradiol $7 \times 10^{-6} \mathrm{M}$ & 603 & 166 & 27.5 & 376 & 62.4 & 61 & 10.1 & 1.83 \\
\hline Oestradiol $7 \times 10^{-5} \mathrm{M}$ & 604 & 186 & 30.8 & 342 & 56.6 & 76 & 12.6 & 1.82 \\
\hline Oestradiol $2.1 \times 10^{-4} \mathrm{M}$ & 618 & 220 & 35.6 & 354 & 57.3 & 44 & 7.1 & 1.72 \\
\hline $\begin{array}{l}\text { Positive control } \\
\text { (MNNG) }\end{array}$ & 601 & 332 & 55.2 & 220 & 36.6 & 49 & 8.2 & $1.53^{* *}$ \\
\hline
\end{tabular}

** $P<0.01$ (Student's $t$-test). $C P I=\left(M_{1}+2 M_{2}+3 M_{3}\right) / 100$, where $M_{1}, M_{2}$ and $M_{3}$ represent the percentage of cells in the first, second and third mitosis, respectively

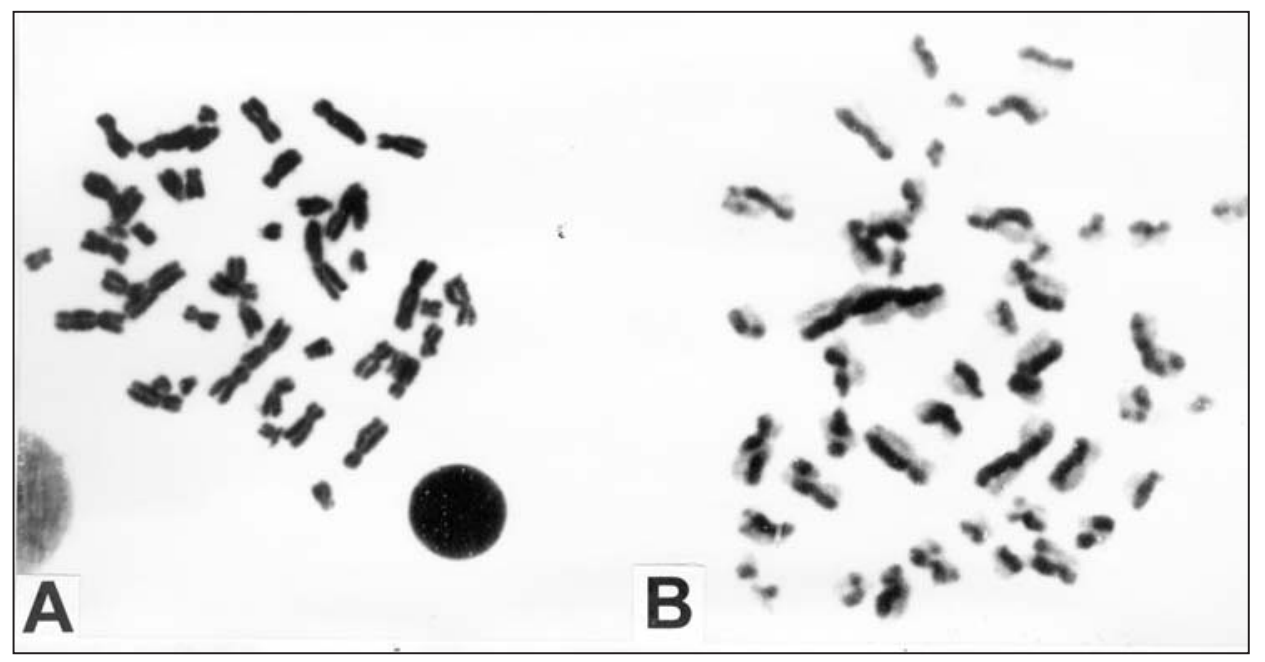

Figure 1. The appearance of metaphase spread in the first $(A)$ and second $(B)$ mitotic division stained by fluoresecence-plus-Giemsa (FPG) technique

Experimental values of chromosome damage and aberration analysis are represented in Table 3. Positive control (MNNG) showed a significant increase of the frequency of cells with gaps and breaks $(P<0.001)$, aneuploidies $(P<0.05)$ 
and polyploidies $(P<0.05)$. Experimental oestradiol concentration of $10^{-10} \mathrm{M}$ comparable with the physiological level of oestradiol in women, was not capable to cause significant changes of the frequency of cells with cytogenetic changes (aneuploidies, polyploideis and chromosome gaps and breaks). Likewise, at a higher concentration $\left(10^{-9} \mathrm{M}\right)$, as well as concentrations corresponding to minimal $\left(7 \times 10^{-8} \mathrm{M}\right)$ and average $\left(3.5 \times 10^{-6} \mathrm{M}\right)$ therapeutic dose, the results on cytogenetic assessment of genotoxic effects of oestradiol were negative. Treatment with oestradiol was efficient in the induction of gaps and breaks and aneuploidies at the three highest concentrations used $\left(7 \times 10^{-6} \mathrm{M}, 7 \times 10^{-5} \mathrm{M}\right.$ and $\left.2.1 \times 10^{-4} \mathrm{M}\right)$ which correspond to the maximal therapeutic dose in human medicine, 10 fold and 30 fold "maximal therapeutic" doses, respectively. Thus, at a concentration of $7 \times 10^{-6}$ $M$ we noticed 5.3-fold increase of gaps and breaks and 2.6-fold increase in aneuploidies. Experimental concentration of $7 \times 10^{-5} \mathrm{M}$ elevated the frequency of cells with gaps and breaks 5-fold, and frequency of cells with aneuploidies 3.4fold. Finally, the highest concentration of oestradiol $\left(2.1 \times 10^{-4} \mathrm{M}\right)$ caused 6-fold increase of gaps and breaks (Fig. 2) and 3.8-fold increase of aneuploidies. Chromosome breaks were also analysed separately form gaps (Tab. 4). In addition to the positive control which caused a significant increase of breaks ( $P$ $<0.01$ ), only the highest concentration of oestradiol had increased the frequency of cells with breaks $(P<0.05)$. Finally, it should be emphasized that oestradiol had no effect on the frequency of polyploid cells. As expected, the well-known mutagen MNNG used as a positive control caused a significant $(P<0.05)$ increase of the frequency of polyploid lymphocytes (Fig. 3).

Table 3. Cytogenetic endpoints in human peripheral blood lymphocytes treated with $17 \beta$-oestradiol

\begin{tabular}{|c|c|c|c|c|c|c|c|c|}
\hline \multirow[t]{2}{*}{ Treatment } & \multicolumn{2}{|c|}{$\begin{array}{l}\text { Observed } \\
\text { cells }\end{array}$} & \multicolumn{2}{|c|}{$\begin{array}{l}\text { Aneuploid } \\
\text { cells }\end{array}$} & \multicolumn{2}{|c|}{$\begin{array}{l}\text { Polyploid } \\
\text { cells }\end{array}$} & \multicolumn{2}{|c|}{$\begin{array}{l}\text { Gaps and } \\
\text { breaks }\end{array}$} \\
\hline & No & $\%$ & No & $\%$ & No & $\%$ & No & $\%$ \\
\hline $\begin{array}{l}\text { Negative control } \\
\text { (DMSO) }\end{array}$ & 150 & 100 & 5 & 3.33 & 1 & 0.67 & 3 & 2.00 \\
\hline Oestradiol $10^{-10} \mathrm{M}$ & 150 & 100 & 6 & 4.00 & 2 & 1.33 & 4 & 2.67 \\
\hline Oestradiol $10^{-9} \mathrm{M}$ & 150 & 100 & 4 & 2.67 & 0 & 0.00 & 1 & 0.67 \\
\hline Oestradiol $7 \times 10^{-8} \mathrm{M}$ & 150 & 100 & 8 & 5.33 & 1 & 0.67 & 8 & 5.33 \\
\hline 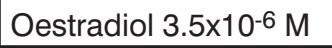 & 150 & 100 & 9 & 6.00 & 1 & 0.67 & 9 & 6.00 \\
\hline Oestradiol $7 \times 10^{-6} \mathrm{M}$ & 150 & 100 & 13 & $8.67^{*}$ & 3 & 2.00 & 16 & $10.67^{* *}$ \\
\hline Oestradiol $7 \times 10^{-5} \mathrm{M}$ & 150 & 100 & 17 & $11.33^{\star *}$ & 2 & 1.33 & 15 & $10.00 * *$ \\
\hline Oestradiol $2.1 \times 10^{-4} \mathrm{M}$ & 150 & 100 & 19 & $12.67^{* *}$ & 2 & 1.33 & 18 & $12.00 * *$ \\
\hline $\begin{array}{l}\text { Positive control } \\
\text { (MNNG) }\end{array}$ & 150 & 100 & 13 & $8.67^{\star}$ & 7 & $4.67^{*}$ & 23 & $15.33^{\star * *}$ \\
\hline
\end{tabular}

Statistical significance: * $P<0.05$; ${ }^{*} P<0.01$; ${ }^{* * *} P<0.001$ (Student's $t$-test). 
Acta Veterinaria (Beograd), Vol. 56. No. 1, 37-48, 2006

Djelić $\mathrm{N}$ et al.: Cell cycle kinetics and cytogenetic changes

in human lymphocytes exposed to oestradiol in vitro

Table 4. Detailed analysis of chromosome gap and break frequencies in human lymphocytes treated with $17 \beta$-oestradiol in vitro

\begin{tabular}{|c|c|c|c|c|c|c|}
\hline \multirow{2}{*}{ Concentration } & \multicolumn{5}{|c|}{ Types of chromosomal changes } & \multirow{2}{*}{$\begin{array}{c}\text { Breaks } \\
(\%)\end{array}$} \\
\hline & G & $\mathrm{CB}$ & IB & CE & IE & \\
\hline Negative control (DMSO) & 1 & 2 & - & - & - & 1.33 \\
\hline Oestradiol 10-10 M & 4 & - & - & - & - & 0.00 \\
\hline Oestradiol $10^{-9} \mathrm{M}$ & 1 & - & - & - & - & 0.00 \\
\hline Oestradiol $7 \times 10^{-8} \mathrm{M}$ & 5 & 3 & - & - & - & 2.00 \\
\hline Oestradiol 3.5x10-6 M & 5 & 3 & 1 & - & - & 2.67 \\
\hline Oestradiol $7 \times 10^{-6} \mathrm{M}$ & 11 & 5 & - & - & - & 3.33 \\
\hline Oestradiol $7 \times 10^{-5} \mathrm{M}$ & 9 & 6 & - & - & - & 4.00 \\
\hline Oestradiol $2.110^{-4} \mathrm{M}$ & 10 & 8 & - & - & - & $6.67^{*}$ \\
\hline Positive control (MNNG) & 11 & 10 & 2 & - & - & $8.00 * *$ \\
\hline
\end{tabular}

G - gaps (not included in statistical analysis); CB - chromatid; IB - isochromatid breaks; CE - chromatid; IE - isochromatid exchange; A total of 150 cells were analysed per each concentation. Statistical significance: * $P<0.001 ; * \star * P<0.001$ ( $\chi^{2}$ test)

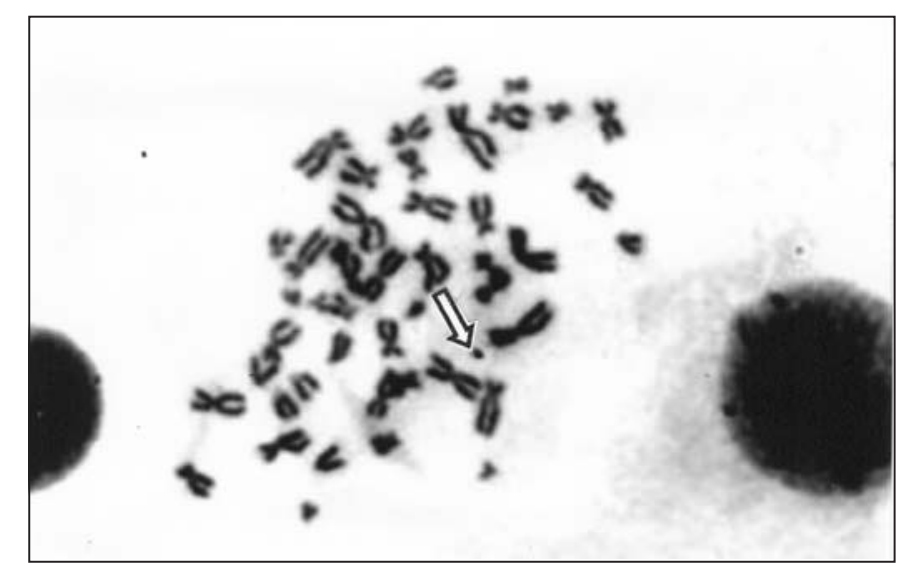

Figure 2. Acentric fragment (indicated by an arrow) in the cell treated with $2.1 \times 10^{-4} \mathrm{M}$ oestradiol 


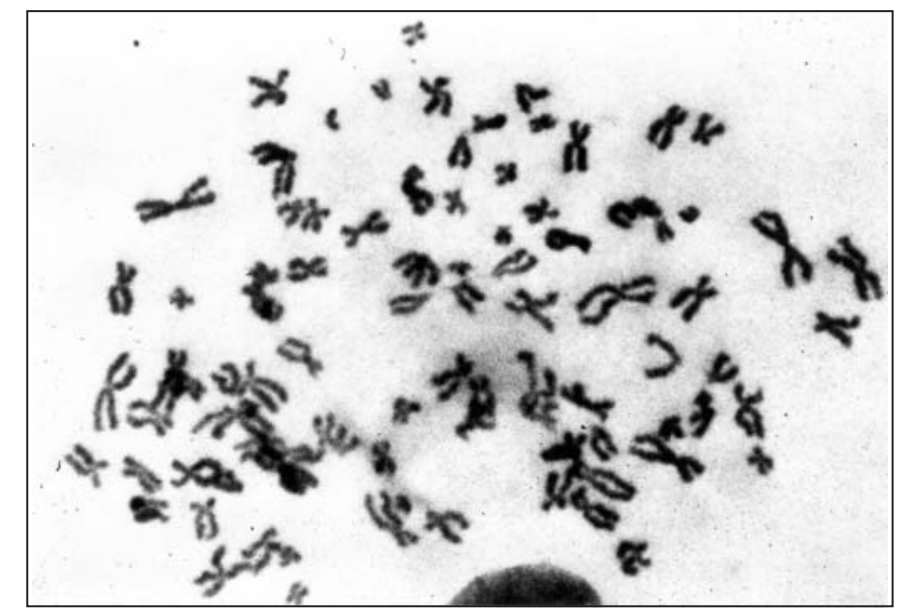

Figure 3. Tetraploid lymphocyte isolated from culture treated with positive control (MNNG, final conc. $10^{-6} \mathrm{M}$ )

\section{DISCUSSION}

Investigations of the effects of endogenous mutagenic agents are complex due to the simple fact that endogenous substances are normally present in animal and human bodies. Therefore, it is unlikely to expect that natural selection during the process of evolution would have allowed the presence of substances capable of disturbing the genetic integrity. On the other hand, a low level of mutations is compatible with survival, and may contribute to changes of the genetic structure of a population, which is important for the long-term evolution process.

Hormones represent one of the best studied group of endogenous mutagens (Djelić and Djelić, 2002). In the present study, we studied the cell cycle kinetics and cytogenetic changes in cultured human lymphocytes exposed to seven experimental concentrations of oestradiol in a range from $10^{-10} \mathrm{M}$ to $2.1 \mathrm{x}$ $10^{-4} \mathrm{M}$. Our data shows that oestradiol at $7 \times 10^{-6} \mathrm{M}$ ("maximal therapeutic dose") and two higher concentrations $\left(7 \times 10^{-5} \mathrm{M}\right.$ and $\left.2.1 \times 10^{-4} \mathrm{M}\right)$ exhibits aneugenic and clastogenic effects. Aneugenic effects imply chromosome lagging during mitosis which leads to aneuploidy. Our results of aneugenic effects are in accordance with the findings which demonstrate the induction of aneuploidies in human and mouse fibroblasts (Tsutsui et al., 1990). It is conceivable that oestadiol induces aneuploidy through mitotic arrest, rather than inhibition of microtubule assembly in vitro (Wheeler et al., 1987).

Clastogenic effects imply DNA damage accompanied by chromosome breakage. In the positive control the well known alkylating agent (MNNG) was an efficient $(P<0.001)$ inducer of gaps and breaks. The three highest concentrations of oestradiol used in this experiment exhibited clastogenic effects. According to modern standpoint phenolic groups of steroidal oestrogens, especially at 
elevated tissue concentrations, are converted to catecholestrogens which can be inculded in redox cycling (Cavalieri and Rogan, 2004). Reactive oxygen species and semiquinones created during the redox cycling of phenolic groups in steroidal or nonsteroidal oestrogens can induce DNA adducts (Rizzati et al., 2005) including 8-hydroxydeoxyguanosine (Liehr, 2000). Incomplete repair of this chemically modified base may lead to creation of DNA breakage which underlies chromosome breakage. Interestingly, in addition to hormonal activity, both natural and synthetic oestrogens containing phenolic structures can have pro-oxidant and/or antioxidant effects depending primarily on their tissue concentrations and presence of metal cations (Liehr and Roy, 1998). In the presence of redox-active metal ions high tissue concentrations of catechol oestrogens exhibit pro-oxidant effects. These effects are evident through oxygen free radical-mediated toxicity such as single-strand DNA breaks, lipid peroxidation, 8-hydroxylation of guanine bases of DNA and chromosomal abnormalities (Liehr and Roy, 1998). Therefore, it is conceivable that high experimental concentrations of oestradiol used in this investigation created oxidative stress and oxidative radical DNA damage. This assumption is supported by experimental findings showing that the DNA damaging effects of oestradiol in single cell gel electrophoresis (Comet) assay were reduced by the antioxidant enzyme catalase both in human lymphocytes (Djelić and Anderson, 2003) and sperm (Anderson et al., 2003). Some of these not completely reparable lesions induced by oestrogen in our investigation, were converted into gaps and/or breaks. These chromosome lesions are a precondition for the formation of structural chromosome aberrations (inversions, translocations and other chromosome rearrangements) (Savage, 2004). However, in this experiments we have not observed any structural chromosome aberrations. Probably, clastogenic effects of high oestradiol concentrations were not high enough to create structural chromosome changes. It is generally acknowledged that unlike ionizing radiation, chemical mutagens (including hormones), as a rule, are not strong inducers of chromosome breakage and structural aberrations (Tucker et al., 2005).

On the other hand, oestradiol has not influenced the frequency of polyploid lymphocytes. Only the positive control (MNNG) caused a significant $(p<0.05)$ increase of the frequency of polyploid cells, possibly interfering in the function of mitotic spindle microtubules (Tsuiki et al., 2001).

To determine the possible cytotoxic, cytostatic or mitogenic effects of oestradiol we analysed the mitotic index (MI) for each experimental concentration, as well as for the controls. In order to avoid possible changes in mitotic activity we used the same quality media and PHA for all experimental cycles. After stimulation of peripheral blood lymphocytes with PHA, the cultures soon contained different generations of cells, i.e. cells that have divided for a different number of times. The heterogeneity of cell division reflects either a difference in the cell cycle duration, or a difference in the times when the cells started blastogenesis in response to PHA (Wheeler et al., 1987). Obviously, oestradiol has not influenced mitotic activity of human lymphocytes compared to the negative control and untreated cultures. Moreover, cell proliferation index (CPI) as a parameter indicating cell cycle progression has not changed in oestradiol-treated cultures. Therefore, 
oestradiol has not exhibited stimulatory or inhibitory effects on mitotic activity and cell cycle kinetics under the described experimental conditions. As expected, the positive control (MNNG) decreased $\mathrm{Ml}$ by $\sim 34 \%$ and CPI by $16.5 \%$ compared to the negative control, possibly due to an arrest of mitosis due to repair of genetic material. Cytotoxic effects occur in cells with a relatively high level of genetic damage (Sordo et al., 2001).

In conclusion, since oestardiol caused some cytogenetic damage we assume that oestradiol use may pose genetic risk at cytogenetic level, especially at high doses, or if used as a therapy over a prolonged period of time. On the other hand, there was no modulatory effect of oestradiol on human lymphocyte proliferation in vitro.

\section{ACKNOWLEDGEMENT}

This investigation was supported by the Serbian Ministry of Science and Environmental Protection, grant \#143018.

Address for correspondence:

Assoc. Prof. Dr Ninoslav Djelić

Department of Biology

Faculty of Veterinary Medicine

University of Belgrade

Bul. JNA 18

11000 Belgrade

Serbia \& Montenegro

E-mail: ndjelicŽvet.bg.ac.yu

\section{REFERENCES}

1. Ahmad ME, Shadab GG, Hoda A, Afzal M, 2000, Genotoxic effects of estradiol-17 $\beta$ on human lymphocyte chromosomes, Mutat Res, 466, 109-15.

2. Anderson D, Schmid TE, Baumgartner A, Cemeli-Carratala E, Brinkworth MH, Wood JM, 2003, Oestrogenic compounds and oxidative stress (in human sperm and lymphocytes in the Comet assay), Mutat Res, 544, 173-8.

3. Banerjee SK, Banerjee S, Li SA, Li JJ, 1994, Induction of chromosome aberrations in Syrian hamster renal cortical cells by various estrogens, Mutat Res, 311, 191-7.

4. Brogger A, 1982, The chromatid gap: a useful parameter in genotoxicology?, Cytogenet Cell Genet, 33, 14-19.

5. Cavalieri E, Frenkel K, Liehr JG, Rogan E, Roy D. 2000, Estrogens as endogenous genotoxic agents - DNA adducts and mutations, J Natl Cancer Inst Monogr 27, 75-93.

6. Cavalieri EL, Rogan EG, 2004, A unifying mechanism in the initiation of cancer and other diseases by catechol quinones, Ann N Y Acad Sci, 1028, 247-57.

7. Djelić N, Anderson D, 2003, The effect of the antioxidant catalase on oestrogens, triodothyroine and noradrenaline in the Comet assay, Teratog Carcinog Mutagen, 23, 69-81.

8. Djelić $N$, Djelić $D, 2002$, Enhanced sister-chromatid exchange rate in human lymphocytes exposed to $17 \beta$ estradiol in vitro, Arch Med Res, 33, 148-51.

9. Djelić N, Spremo-Potparević B, Djelić $D, 2005$, Mutagenic activity of estradiol evaluated by an in vitro micronucleus assay, Acta Biol Hung, 56, 403-6.

10. Evans HJ, O'Riordan ML, 1975, Human peripheral blood lymphocytes for the analysis of chromosome aberrations in mutagen tests, Mutat Res, 31, 135-48.

11. Hundal BS, Dhillon VS, Sidhu IS, 1997, Genotoxic potential of estrogens, Mutat Res, 389, 173-81. 
12. IARC, 1979, IARC Monographs on the evaluation of the carcinogenic risk of chemicals to humans: Sex hormones (II), International Agency for Research on Cancer, Lyon, France, IARC Monogr Eval Carcinog Risk Chem Hum 21, 11-561.

13. IARC, 1987, Monographs on the evaluation of carcinogenic risks to humans. International Agency for Research on Cancer. Lyon, France, IARC Monogr Eval Carcinog Risk Chem Hum Suppl. 7, 280-5.

14. IARC, 1999, Monographs on the evaluation of carcinogenic risks to humans: Hormonal contraception and postmenopausal hormone therapy, International Agency for Research on Cancer, Lyon, France, IARC Monogr Eval Carcinog Risk Chem Hum vol. 72.

15. Krikman H, 1959, Oestrogen-induced tumors of the kidney. III Growth characteristics in the Syrian hamster, Natl Cancer Inst Monogr, 1, 1-57.

16. Liehr JG, 2001, Genotoxicity of steroidal estrogens estrone and estradiol: possible mechanism of uterine and mammary cancer development, Hum Reprod Update, 7, 273-81.

17. Liehr JG, 2000, Role of DNA adduct in hormonal carcinogenesis, Regul Toxicol Pharmacol, 32, 27682.

18. Liehr JG, Gladek A, Macatee T, Randerath E, Randerath K, 1991, DNA adduct formation in liver and kidney of male Syrian hamsters treated with estrogen and/or alpha-naphtoflavone, Carcinogenesis, 12, 385-9.

19. Liehr JG, Roy D, 1990, Free radical generation by redox cycling of oestrogens, Free Radic Biol Med, 8, 415-23.

20. Liehr JG, Roy D, 1998, Pro-oxidant and antioxidant effects of estrogens, Methods Mol Biol, 108 , 425-35.

21. Papa D, Li SA, Li JJ, 2003, Comparative genomic hybridization of estrogen-induced ectopic uterine-like stem cell neoplasms in the hamster kidney: nonrandom chromosomal alterations, Mol Carcinog, 38, 97-105.

22. Perry P, Wolff S 1974, New Giemsa method for the differential staining of sister chromatids, Nature 251, 156-8.

23. Platet N, Cathiard AM, Gleizes M, Garcia M, 2004, Estrogens and their receptors in breast cancer progression: a dual role in cancer proliferation and invasion, Crit Rev Oncol Hematol, 51, 55-67.

24. Rajapakse N, Butterworth M, Kortenkamp A, 2005, Detection of DNA strand breaks and oxydized DNA bases at the single-cell level resulting from exposure to estradiol and hydroxylated metabolites, Environ Mol Mutagen, 45, 397-404.

25. Rizzati V, Rathahao E, Gamet-Payrastre L, Delous G, Jouanin I, Gueraud F, Paris A, 2005, In vitro aromatic bioactivation of the weak estrogen $\mathrm{E}_{2} \alpha$ and genesis of DNA adducts, Steroids, 70, 161-72.

26. Savage JR, 2004, On the nature of visible chromosomal gaps and breaks, Cytogenet Genome Res, 104, 46-55

27. Sordo M, Herrera LA, Ostrosky-Wegman P, Rojas E, 2001, Cytotoxic and genotoxic effects of As, MMA, and DMA on leukocytes and stimulated human lymphocytes, Teratog Carcinog Mutagen, 21, 249-60.

28. Tsuiki H, Nitta M, Tada M, Inagaki M, Ushio Y, Saya H, 2001, Mechanism of hyperploid cell formation induced by microtubule inhibiting drug in glioma cell lines, Oncogene, 20, 420-9.

29. Tsutsui T, Suzuki N, Maizumi H, Barret C 1990, Aneuploidy induction in human fibroblasts: comparison with results in Syrian hamster fibroblasts, Mutat Res, 240, 241-9.

30. Tucker JD, Cofield J, Matsumoto K Ramsey MJ, Freeman DC 2005, Persistence of chromosome aberrations following acute radiation: I, PAINT translocations, dicentrics, rings, fragments, and insertions, Environ Mol Mutagen, 45, 229-48.

31. Walker BE 1983, Uterine tumors in old female mice exposed prenatally to diethylstilbestrol. J Nat Cancer Inst, 70, 477-84.

32. Wheeler WJ, Hsu TC, Tousson A, Brinkley BR 1987, Mitotic inhibition and chromosome displacement induced by estradiol in Chinese hamster cells, Cell Motil Cytoskeleton, 7, 235-47. 


\title{
KINETIKA PROLIFERACIJE I CITOGENETIČKE PROMENE U HUMANIM LIMFOCITIMA POD DEJSTVOM ESTRADIOLA IN VITRO
}

\author{
DJELIĆ N, SPREMO-POTPAREVIĆ BILJANA, MARKOVIĆ BILJANA, ŽIVKOVIĆ LADA \\ i DJELIĆ DIJANA
}

\section{SADRŽAJ}

Metabolička konverzija fenolnih grupa estrogenih hormona može da dovede do oksidativnog stresa praćenog oštećenjima različitih makromolekula u ćeliji, uključujući DNK. Cilj ovog istraživanja je evaluacija kinetike proliferacije i mogućih citogenetičkih promena u kulturama humanih limfocita pod dejstvom sedam eksperimentalnih koncentracija $17 \beta$-estradiola (opseg od $10^{-10} \mathrm{M}$ do $10^{-4} \mathrm{M}$ ).

Kinetika proliferacije limfocita analizirana je na metafaznim figurama obojenim tehnikom FPG za standardne analize razmena sestrinskih hromatida (SCE). Citogenetičke promene praćene su analizama hromozomskih oštećenja (gapovi i prekidi), strukturnih i numeričkih aberacija hromozoma.

$\mathrm{Na}$ osnovu dobijenih rezultata može se zaključiti da estradiol ne utiče značajno na mitotsku aktivnost i kinetiku proliferacije limfocita u kulturi. Međutim, pri koncentraciji od $7 \times 10^{-6} \mathrm{M}$, kao i pri višim eksperimentalnim koncentracijama korišćenim u ovim eksperimentima, zapažen je porast gapova, prekida i aneuploidija. S druge strane, tretman estradiolom ne menja učestalost poliploidnih ćelija. Prema tome, može se zaključiti da visoke koncentracije estradiola izazivaju izvestan genetički rizik koji se može detektovati na citogenetičkom nivou. 